\title{
PENGARUH BEBERAPA BAHAN BAKU TERHADAP KARAKTERISTIK FISIKOKIMIA DAN SENSORI RENGGINANG SINGKONG (Manihot utilissima Pohl)
}

\author{
[Effects of Different Types of Raw Material on Physicochemical and Sensory \\ Characteristics of Cassava (Manihot utilissima Pohl) Rengginang] \\ Hadi Munarko dan Sugiyono* \\ Departemen IImu dan Teknologi Pangan, Fakultas Teknologi Pertanian, Institut Pertanian Bogor, Bogor
}

Diterima 12 Juli 2018 / Disetujui 3 Desember 2018

\begin{abstract}
Cassava rengginang is a traditional food having similar shape to rice rengginang but is made from cassava. The objective of this research was to know the effects of raw material on the physical and sensory characteristics of cassava rengginang. This research was divided into two steps. The first step was raw material preparation i.e. grated cassava, cassava flour, and a mixture of tapioca and "asian" flour 3:1 $(w: w)$. The second step was the production of the cassava rengginang from the three raw materials. The results showed that the raw material affected the physical characteristics of cassava rengginang. Rengginang made from grated cassava had the lowest expansion ratio and crispness, i.e. $142.94 \%$ and 474.12 gf respectively. Rengginang made from cassava flour had higher expansion ratio and crispness (191.39\% and $343.81 \mathrm{gf}$ respectively), the lowest lightness $(L=71.4)$ and the highest brownish color $(a=5.18$; $b=27.49$ ). Rengginang from a mixture of tapioca and "asian" flour (3:1) had the highest crispness (244.63 $g f)$, expansion ratio (223.95\%), lightness ( $L=79.62)$, and white color $(a=0.63$ and $b=16.3)$. The differences on the physical characteristics of rengginang did not affect the sensory acceptance of the product for all attributes. Fried rengginang made from a mixture of tapioca and "asian" flour was chosen for proximate analysis because it had the highest expansion ratio, crispness and lightness among the other formula although it was not significantly different at 95\% level on panelist acceptance.
\end{abstract}

Keywords: cassava, color, crispness, expansion ratio, rengginang

\begin{abstract}
ABSTRAK
Rengginang singkong merupakan makanan tradisional yang berbentuk seperti rengginang beras pada umumnya namun berasal dari bahan baku singkong. Tujuan dari penelitian ini adalah untuk mengetahui pengaruh bahan baku terhadap karakteristik fisik dan sensori rengginang singkong. Penelitian ini dibagi menjadi dua tahap. Tahap pertama adalah persiapan bahan baku berupa singkong parut, tepung singkong, campuran tapioka dan tepung asia 3:1 (b:b). Tahap kedua adalah pembuatan rengginang singkong dari ketiga bahan baku. Hasil penelitian menunjukkan bahwa bahan baku memberikan pengaruh nyata terhadap karakteristik fisik rengginang singkong. Rengginang dari singkong parut memiliki rasio pengembangan dan kerenyahan paling rendah, yaitu masing-masing sebesar $142,94 \%$ dan 474,12 gf. Rengginang dari tepung singkong memiliki rasio pengembangan dan kerenyahan lebih tinggi $(191,39 \%$ dan $343,81 \mathrm{gf})$, tetapi memiliki tingkat kecerahan paling rendah $(L=71,4)$ dan cenderung berwarna coklat $(a=5,18 ; b=27,49)$. Rengginang dari campuran tapioka dan tepung asia (3:1) memiliki kerenyahan 244,63 gf, rasio pengembangan $223,95 \%$, tingkat kecerahan $(L) 79,62$, dan warna putih $(a=0,63$ dan $b=16,3)$ tertinggi dibandingkan dengan formula yang lain. Perbedaan karakteristik fisik tersebut tidak berpengaruh terhadap penerimaan panelis untuk semua atribut sensori rengginang singkong matang. Rengginang singkong dari campuran tapioka dan tepung asia dipilih untuk dianalisis proksimat karena memiliki volume pengembangan, tingkat kerenyahan, dan kecerahan yang paling tinggi diantara perlakuan lainnya meskipun hasil penerimaan panelis terhadap rengginang matang tidak berbeda nyata pada taraf $95 \%$.
\end{abstract}

Kata kunci: kerenyahan, rasio pengembangan, rengginang, singkong, warna

\section{PENDAHULUAN}

Indonesia memiliki kekayaan sumberdaya alam dengan hasil pertanian yang sangat melimpah.

${ }^{*}$ Penulis Korespondensi:

E-mail: ssugiyono@yahoo.com.au
Salah satu komoditas tanaman pangan sumber karbohidrat di Indonesia adalah singkong. Singkong memiliki produktivitas yang paling tinggi dibandingkan dengan tanaman pangan lain seperti padi, jagung, kedelai, dan ubi jalar. Produktivitas singkong pada tahun 2015 mencapai 229,51 kuintal/hektar. 
Total produksi singkong pada tahun 2015 sebanyak 21,8 juta ton, menempati peringkat kedua setelah padi dengan total produksi 75,4 juta ton (BPS, 2017).

Pengolahan singkong menjadi beberapa produk turunan telah dikembangkan oleh industri pangan dan non pangan dengan skala industri yang berbeda-beda. Industri pengolahan singkong skala usaha kecil dan menengah (UKM) biasanya mengolah singkong menjadi berbagai macam olahan makanan tradisional, salah satunya adalah rengginang singkong. Rengginang singkong merupakan rengginang yang dibuat dari singkong yang dibentuk bulatanbulatan kecil menyerupai bentuk rengginang beras. Rengginang singkong telah dikembangkan oleh UKM di beberapa daerah seperti di Bojonegoro (Hendrasmoro, 2012). Pengolahan rengginang singkong skala rumah tangga memiliki nilai tambah produk yang cukup tinggi dan layak untuk dijalankan (Elida dan Hamidi, 2009).

Sediaan bahan baku dalam pembuatan produk olahan singkong memiliki peranan penting dalam penentuan mutu produk akhir. Singkong segar hanya dapat bertahan 3 sampai 4 hari penyimpanan pada suhu ruang. Singkong segar memiliki kadar air yang tinggi yaitu $58,42 \%$ sehingga berpotensi mengalami kerusakan mikrobiologi. Selain itu, singkong memiliki kandungan total karbohidrat sebanyak 36,96\% (b.b) (Ginting, 2014). Total padatan dari umbi singkong didominasi oleh komponen pati dengan kisaran 70-80\% (Rasulu et al., 2012; Zhu et al., 2015; Charoenkul et al., 2011). Singkong dapat dikeringkan dan digiling menjadi tepung singkong, atau diekstraksi patinya menghasilkan tapioka dan limbah padatnya dimanfaatkan sebagai tepung asia. Teknik ekstraksi dilakukan sangat menentukan rendemen tapioka yang dihasilkan. Kusumawardhani (2013) melaporkan bahwa rendemen tapioka dari singkong yang ada di pasar tradisional berkisar antara $8-12 \%$.

Pembuatan rengginang singkong skala UKM masih menggunakan singkong parut sebagai bahan baku. Tahapan persiapan bahan baku memerlukan waktu lebih lama untuk mengupas, memarut, memeras, dan mengendapkan pati umbi singkong. Selama ini belum ada penelitian yang berhubungan dengan pengolahan rengginang singkong termasuk dalam sediaan bahan baku. Penelitian pembuatan rengginang singkong dari sediaan bahan baku lain diperlukan agar diperoleh alternatif bahan baku pembuatan rengginang singkong yang lebih efisien. Penelitian ini bertujuan untuk mengetahui pengaruh bahan baku terhadap karakteristik fisik rengginang singkong berupa dimensi rengginang singkong, spread factor, rasio pengembangan, kekerasan, kerenyahan, dan warna, serta analisis sensori dengan atribut warna, tekstur, rasa, aroma, dan keseluruhan.

\section{BAHAN DAN METODE}

\section{Bahan}

Bahan yang digunakan dalam penelitian ini adalah singkong varietas Manggu yang berumur 710 bulan yang diperoleh dari petani di sekitar kampus IPB, air, garam dapur, bawang putih, penguat rasa monosodium glutamat (MSG), dan minyak goreng sawit.

\section{Persiapan bahan baku}

Tahap persiapan bahan baku dilakukan dengan pembuatan singkong parut, tepung singkong, tapioka, dan tepung asia. Pembuatan singkong parut dilakukan dengan mengupas singkong, mencuci sampai bersih, dan memarut dengan mesin pemarut. Parutan kemudian direndam dengan larutan natrium metabisulfit 3000 ppm selama 15 menit dengan perbandingan 1:1 (b:b). Hasil parutan dipress dan diendapkan selama 3 jam (Syamsir et al., 2011), kemudian air dibuang dan pati yang dihasilkan dicampurkan kembali dengan ampas singkong. Singkong parut yang dihasilkan dianalisis rendemen dan kadar airnya.

Pembuatan tepung singkong dilakukan dengan mengupas singkong, mencuci hingga bersih, mengiris singkong dengan tebal $2 \mathrm{~mm}$ menggunakan mesin slicer, dan merendamnya dengan larutan natrium metabisulfit 3000 ppm selama 15 menit. Singkong ditiriskan dan dan dikeringkan menggunakan cabinet dryer pada suhu $60^{\circ} \mathrm{C}$ selama 6 jam. Singkong lalu digiling menggunakan pin disc mill yang dilengkapi saringan 60 mesh. Pembuatan tapioka dan tepung asia mengacu pada penelitian Syamsir et al. (2011) yang dimodifikasi pada penambahan larutan natrium metabisulfit dan waktu pengendapan pati. Umbi singkong dikupas, dicuci sampai bersih, diparut, kemudian direndam dengan larutan natrium metabisulfit 3000 ppm selama 15 menit. Selanjutnya, dilakukan ekstraksi pati secara kontinyu menggunakan pulper dengan air mengalir dan ditampung pada wadah penampungan. Ekstraksi dilakukan sampai air yang digunakan tidak berwarna keruh. Air berisi ekstrak pati didiamkan selama semalam sampai semua pati mengendap (dicirikan dengan endapan pati menjadi licin). Selanjutnya, air dibuang, endapan pati dikeringkan dan digiling untuk dijadikan tapioka. Ampas umbi singkong juga dikeringkan dan digiling menjadi tepung asia. Pengeringan dilakukan dengan menggunakan cabinet dryer pada suhu $60^{\circ} \mathrm{C}$ selama 3 jam, sedangkan penggilingan dilakukan dengan menggunakan pin disc mill yang dilengkapi saringan 60 mesh.

\section{Pembuatan rengginang singkong}

Pembuatan rengginang singkong meliputi tahapan pengadonan, pencetakan, pengukusan, pengeringan, dan penggorengan. Perlakuan bahan ba- 
ku yang digunakan dalam pembuatan rengginang singkong yaitu singkong parut (Formula $A$ ), tepung singkong (Formula B), serta campuran tapioka dan tepung asia dengan perbandingan 3:1 (Formula $C$ ). Penggunaan perbandingan tapioka:tepung asia sebanyak 3:1 didasarkan pada hasil ekstraksi singkong pada penelitian ini yang menghasilkan tapioka sekitar 3 bagian dan tepung asia sekitar 1 bagian. Penambahan air pada pembuatan adonan rengginang harus dikontrol agar butiran-butiran adonan rengginang dapat terbentuk. Berdasarkan hasil trial formula $A$, butiran adonan terbentuk dengan baik dengan penambahan air sebanyak $10,92 \mathrm{~mL}$ (dari 100 gram bahan baku) atau setara dengan kadar air $50 \%$. Hasil trial ini digunakan sebagai dasar perhitungan kesetimbangan massa dalam menentukan jumlah air pada formula $\mathrm{B}$ dan $\mathrm{C}$.

Hasil perhitungan kesetimbangan massa diperoleh penambahan air pada formula $B$ sebanyak $83,34 \mathrm{~mL}$, formula $\mathrm{C}$ sebanyak $86,81 \mathrm{~mL}$ (dari 100 gram berat bahan baku). Hasil tersebut kemudian diujicobakan pada pembuatan adonan. Uji coba penambahan air pada formula $B$ telah menghasilkan butiran adonan yang seragam, namun pada formula $\mathrm{C}$ adonan masih berbentuk tepung halus dan belum terbentuk butiran. Oleh karena itu, penentuan penambahan air pada formula $C$ unuk mendapatkan butiran adonan yang seragam dilakukan dengan trial (Tabel 1) dan diperoleh penambahan air sebanyak $105 \mathrm{~mL}$ untuk setiap 100 gram bahan baku formula C. Formulasi rengginang singkong ketiga formula disajikan pada Tabel 2.
Tabel 1. Pengaruh penambahan air terhadap adonan formula $\mathrm{C}$ secara deskriptif

\begin{tabular}{cl}
\hline Jumlah Air (\%) & \multicolumn{1}{c}{ Deskripsi Adonan } \\
\hline 87 & $\begin{array}{l}\text { Adonan masih dalam bentuk tepung } \\
\text { halus } \\
\text { Sebagian besar adonan masih } \\
\text { halus, sudah mulai terbentuk butiran }\end{array}$ \\
100 & $\begin{array}{l}\text { Butiran adonan yang terbentuk } \\
\text { semakin banyak } \\
\text { Butiran adonan yang terbentuk } \\
\text { secara visual sudah seragam dan } \\
\text { menyerupai adonan formula lain } \\
\text { Adonan terlalu basah dan susah } \\
\text { untuk diayak }\end{array}$ \\
\hline
\end{tabular}

Pembuatan rengginang singkong dilakukan dengan menghaluskan garam, bawang putih, dan MSG. Bumbu halus kemudian dilarutkan dalam air dan dicampur dengan bahan baku singkong dengan bantuan hand mixer sampai terbentuk butiran adonan yang seragam. Adonan diayak dengan diameter lubang $5 \mathrm{~mm}$ dan dicetak ke dalam pelat logam berbentuk lingkaran. Adonan yang telah dicetak kemudian dikukus selama lima menit. Setelah dikukus, rengginang diletakkan ke loyang dan dikeringkan dengan menjemurnya langsung di bawah sinar matahari hingga kering. Penjemuran dilakukan dari pukul 09:00-15:00 selama 2-3 hari. Ciri-ciri rengginang telah kering adalah berwarna mengkilap dan mudah dipatahkan. Penggorengan dilakukan selama 30 detik pada suhu $172 \pm 1^{\circ} \mathrm{C}$. Bentuk produk rengginang singkong mentah dan matang disajikan pada Gambar 1.

A: Rengginang Mentah
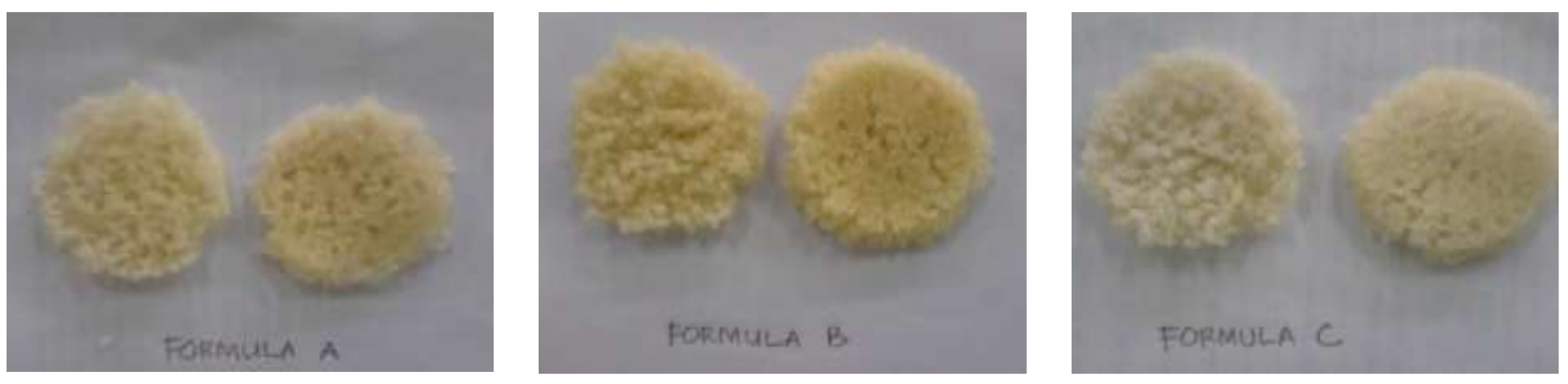

B: Rengginang Matang
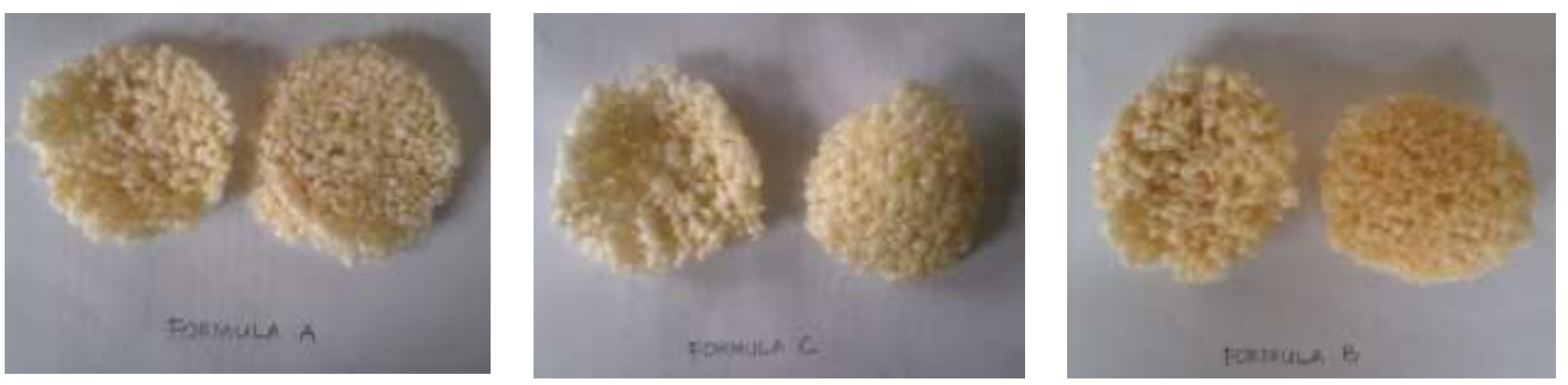

Gambar 1. Bentuk rengginang singkong mentah dan matang 
Tabel 2. Formulasi pembuatan rengginang singkong

\begin{tabular}{lcccccc}
\hline \multirow{2}{*}{ Komposisi } & \multicolumn{3}{c}{ Formula $\mathrm{A}$} & \multicolumn{2}{c}{ Formula B } & \multicolumn{2}{c}{ Formula C } \\
\cline { 2 - 7 } & $\mathrm{g}^{*}$ & $\%(\mathrm{~g} / 100 \mathrm{~g} \text { total })^{\star *}$ & $\mathrm{~g}^{*}$ & $\%(\mathrm{~g} / 100 \mathrm{~g} \text { total })^{\star *}$ & $\mathrm{~g}^{*}$ & $\%(\mathrm{~g} / 100 \mathrm{~g} \text { total })^{\star *}$ \\
\hline Bahan baku & 100,00 & 88,32 & 100,00 & 53,42 & 100,00 & 47,87 \\
Air & 10,92 & 9,64 & 83,34 & 44,52 & 105,00 & 50,26 \\
Garam & 1,50 & 1,32 & 2,50 & 1,34 & 2,55 & 1,22 \\
Bawang putih & 0,70 & 0,62 & 1,17 & 0,63 & 1,19 & 0,57 \\
MSG & 0,10 & 0,09 & 0,17 & 0,09 & 0,17 & 0.08 \\
\hline Total & 113,22 & 100 & 187,18 & 100 & 208,91 & 100 \\
\hline
\end{tabular}

Keterangan: *Perhitungan dengan kesetimbangan massa per 100 gram bahan baku singkong; ${ }^{* * P e r s e n t a s e}$ berdasarkan berat total; A = Bahan dari singkong parut (kadar air 45,69\%); B = Bahan dari tepung singkong (kadar air 9,64\%); C = Bahan dari tapioka (kadar air 7,60\%):tepung asia (kadar air 8,34\%) (3:1)

\section{Analisis bahan baku dan rengginang singkong}

Analisis dilakukan terhadap matrik bahan baku dan rengginang singkong. Bahan baku pembuatan rengginang singkong dianalisis dengan menetapkan kadar air (AOAC, 2005), derajat putih (Kusumawardhani, 2013), dan kehalusan (Kusumawardhani, 2013). Rengginang singkong dianalisis dengan mengukur sifat fisik dan sensorinya. Analisis fisik rengginang singkong meliputi analisis dimensi rengginang singkong (massa, tebal, dan diameter), spread factor (Baljeet et al., 2010), rasio pengembangan (Huda et al., 2011), kekerasan dan kerenyahan menggunakan texture analyzer TA-XT2 (Texture Technologies Corp., UK) dengan probe compression berbentuk bola ukuran $0,5 \mathrm{~s}$, serta analisis warna menggunakan chromameter CR 300 (Minolta, Jepang) dengan sistem notasi Hunter L, a, dan b.

Pengujian penerimaan panelis terhadap rengginang singkong mengacu pada Setyaningsih et al. (2010) menggunakan 30 panelis dengan metode uji rating hedonik. Pengujian dilakukan terhadap rengginang mentah dengan atribut kenampakan dan rengginang matang dengan atribut warna, tekstur, rasa, aroma, dan keseluruhan. Skala yang digunakan adalah 1 sampai 7 dari sangat tidak suka sampai sangat suka. Penetapan formula terpilih didasarkan pada hasil analisis sensori dan hasil analisis fisik rengginang singkong matang. Analisis proksimat produk terpilih meliputi analisis kadar air metode oven, analisis kadar abu dengan tanur, Analisis kadar protein metode kjeldahl, analisis kadar lemak metode soxhlet, dan analisis karbohidrat by difference (AOAC, 2005).

\section{Analisis data}

Data hasil analisis fisik dan sensori yang diperoleh disajikan dalam bentuk rata-rata dan dianalisis statistika menggunakan SPSS 20.0 dengan analisis ragam (ANOVA) dan uji lanjut Duncan.

\section{HASIL DAN PEMBAHASAN}

\section{Karakteristik bahan baku dan pembuatan renggi- nang singkong}

Tabel 3 menunjukkan analisis terhadap bahan baku yang digunakan dalam pembuatan rengginang singkong. Analisis kadar air, derajat putih, dan kehalusan pada tepung singkong dan tapioka telah memenuhi standar SNI (BSN, 1996; BSN, 2011). Secara umum, rendemen tertinggi terdapat pada singkong parut yang masih memiliki kadar air tinggi, yaitu antara $45-55 \%$. Keragaman kadar air yang cukup besar terjadi tergantung dari kekuatan pengepresan yang dilakukan. Sementara rendemen paling rendah adalah tepung asia sebanyak $8,55 \%$. Faktor-faktor yang dapat memengaruhi rendemen dari tepung maupun pati yang dihasilkan diantaranya varietas dan umur panen singkong (Feliana et al., 2014).

Penambahan air pada adonan formula $\mathrm{C}$ agar terbentuk butiran adonan yang baik dibutuhkan jumlah air yang lebih banyak dibandingkan dengan formula A dan B. Hal ini diduga karena pati tapioka memiliki kemampuan mengikat air yang lebih banyak dibandingkan dengan tepung singkong. Pati yang terbebas dari matriks bahan pangan memberikan kesempatan untuk mengikat air lebih banyak dibandingkan dengan pati yang masih terperangkap di dalam matriks bahan seperti pada tepung singkong. Menurut Muhandri (2012) dalam penelitiannya tentang mi jagung, granula pati pada tepung jagung tidak terpisah secara sempurna sehingga ikatan hidrogen yang terjadi antara molekul pati dan air pada mi jagung hanya terbatas pada granula pati yang terbebas dari granula tepung jagung.

\section{Pengaruh bahan baku terhadap karakteristik fi- sik rengginang singkong}

Analisis fisik rengginang singkong dilakukan untuk mengetahui pengaruh dari masing-masing formula terhadap karakteristik fisik rengginang singkong. Berdasarkan hasil pada Tabel 4, terjadi perubahan dimensi rengginang singkong setelah proses penggorengan. Hal ini disebabkan adanya proses penggorengan mampu meningkatkan dimensi rengginang singkong.

Pengukuran spread factor dilakukan dengan menghitung perbandingan antara perubahan diameter dengan perubahan tebal rengginang singkong. Nilai spread factor ini menunjukkan arah pengembangan rengginang singkong. Nilai spread factor yang besar menunjukkan arah pengembangan secara horizontal sedangkan nilai spread factor yang 
kecil menunjukkan arah pengembangan vertikal (Nashirudin, 2009). Hasil analisis spread factor terhadap produk rengginang pada Tabel 5 menunjukkan bahwa ketiga perlakuan tidak berbeda signifikan pada taraf nyata $5 \%$. Nilai spread factor ketiga perlakuan tersebut memiliki rata-rata antara 58,29\%$60,66 \%$. Naveen et al. (2013) menjelaskan bahwa salah satu faktor yang memengaruhi nilai spread factor adalah kadar protein. Semakin tinggi kadar protein suatu bahan secara signifikan menurukan nilai spread factor.

Rasio pengembangan merupakan persentase dari perbandingan perubahan volume rengginang selama penggorengan dengan volume rengginang mentah. Berdasarkan hasil analisis pada Tabel 5 , rasio pengembangan ketiga sampel tersebut berbeda signifikan. Rengginang singkong dari singkong parut memiliki nilai rasio pengembangan paling kecil (142,94\%). Rengginang singkong dari tepung singkong berada pada subset kedua (191,39\%), sedangkan rengginang dari campuran tapioka dan tepung asia memiliki nilai rasio pengembangan paling besar (223,95\%). Menurut Norton et al. (2011), mekanisme pengembangan dari produk penggorengan merupakan hasil dari sejumlah letusan air terikat yang menguap dengan cepat selama proses penggoreng- an sehingga terbentuk rongga-rongga udara pada produk. Pati telah dilaporkan memiliki peranan utama dalam mengatur pengembangan volume produk snack berbasis pati (Mustapha et al., 2015). Komponen pati yang telah tergelatinisasi mampu mengembang selama penggorengan (Nurul et al., 2009). Proses gelatinisasi membutuhkan panas dan air yang cukup sehingga pati dapat tergelatinisasi sempurna dan ketika kerupuk digoreng mampu mengembang sempurna (Huda et al., 2010). Saeleaw dan Schleining (2011) menambahkan bahwa kombinasi suhu dan waktu penggorengan yang optimum dapat berpengaruh signifikan terhadap peningkatan pengembangan linear kerupuk.

Keterikatan pati di dalam matriks bahan dapat memengaruhi tingkat pengembangan rengginang selama penggorengan. Pati yang terbebas dari matriks pangan dapat meningkatkan derajat gelatinisasi dan pengembangan rengginang saat di goreng. Ahmad (2009) melaporkan bahwa penggilingan dapat meningkatkan derajat gelatinisasi dan menyebabkan lebih banyak amilosa keluar dari granula pati, dan Muhandri (2012) menambahkan bahwa tidak semua pati dapat terpisah sempurna dari granula tepung.

Tabel 3. Karakterisasi tepung singkong, tapioka, tepung asia, dan singkong parut

\begin{tabular}{lcccc}
\hline \multicolumn{1}{c}{ Analisis } & Tepung Singkong & Tapioka & Tepung Asia & Singkong Parut \\
\hline Rendemen (\%) & 40,34 & 23,08 & 8,55 & 65,90 \\
Kadar air (\%) & $9,50 \pm 0,02$ & $7,60 \pm 0,01$ & $8,34 \pm 0,06$ & $45,69-54,60$ \\
Derajat putih (\%) & $91,50 \pm 0,11$ & $97,31 \pm 0,45$ & $89,61 \pm 0,15$ & - \\
Kehalusan (\%) & & & & - \\
lolos 100 mesh & 77,01 & 88,02 & 51,82 & - \\
lolos 120 mesh & 73,22 & 85,55 & 47,59 & - \\
lolos 150 mesh & 71,19 & 84,17 & 45,11 & \\
\hline
\end{tabular}

Keterangan: (-) Tidak dianalisis

Tabel 4. Dimensi rengginang singkong mentah dan matang

\begin{tabular}{lcccc}
\hline Rengginang & Formula & Massa $(\mathrm{g}) \pm$ SD & Tebal $(\mathrm{mm}) \pm$ SD & Diameter $(\mathrm{mm}) \pm$ SD \\
\hline Mentah & A & $5,37 \pm 0,21$ & $6,62 \pm 0,78$ & $47,00 \pm 0,44$ \\
& B & $5,80 \pm 0,39$ & $6,34 \pm 0,01$ & $44,36 \pm 0,86$ \\
& C & $5,42 \pm 0,15$ & $6,00 \pm 0,50$ & $46,00 \pm 1,54$ \\
\hline Matang & A & $6,74 \pm 0,95$ & $10,87 \pm 0,85$ & $63,68 \pm 0,86$ \\
& B & $7,87 \pm 0,45$ & $11,41 \pm 0,72$ & $65,43 \pm 1,50$ \\
& C & $7,52 \pm 0,54$ & $11,44 \pm 0,84$ & $70,41 \pm 4,63$ \\
\hline
\end{tabular}

Keterangan: $\mathrm{A}=$ Bahan dari singkong parut; $\mathrm{B}=$ Bahan dari tepung singkong); $\mathrm{C}=$ Bahan dari campuran tapioka:tepung asia (3:1)

Tabel 5. Hasil analisis fisik rengginang singkong

\begin{tabular}{|c|c|c|c|c|c|c|c|}
\hline \multirow{2}{*}{ Formula } & \multirow{2}{*}{$\begin{array}{c}\text { Spread } \\
\text { Factor (\%) }\end{array}$} & \multirow{2}{*}{$\begin{array}{c}\text { Rasio } \\
\text { Pengembangan (\%) } \\
\end{array}$} & \multirow{2}{*}{$\begin{array}{c}\text { Kerenyahan } \\
\text { (Kerapuhan) (gf) }\end{array}$} & \multirow{2}{*}{ Kekerasan (gf) } & \multicolumn{3}{|c|}{ warna } \\
\hline & & & & & $\mathrm{L}$ & $\mathrm{a}$ & $\mathrm{b}$ \\
\hline$A$ & $58,29 \pm 19,88^{a}$ & $142,94 \pm 28,29^{\mathrm{a}}$ & $474,12 \pm 163,60^{b}$ & & $\begin{array}{l}75,23 \pm \\
1,16^{\mathrm{b}}\end{array}$ & $\begin{array}{l}0,86 \pm \\
0,83^{b}\end{array}$ & $\begin{array}{l}21,60 \pm \\
4,2^{b}\end{array}$ \\
\hline B & $60,66 \pm 11,77^{a}$ & $191,39 \pm 42,02^{b}$ & $343,81 \pm 112,58^{a}$ & $3410,76 \pm 706,54^{a}$ & $\begin{array}{l}71,40 \pm \\
1,05^{\mathrm{a}}\end{array}$ & $\begin{array}{l}5,18 \pm \\
0,73^{\mathrm{c}}\end{array}$ & $\begin{array}{c}27,49 \pm \\
2,20^{c}\end{array}$ \\
\hline C & $59,47 \pm 11,42^{a}$ & $223,95 \pm 29,14^{\mathrm{C}}$ & $244,63 \pm 105,16^{a}$ & $2946,49 \pm 681,07^{a}$ & $\begin{array}{c}79,62 \pm \\
0,90^{c}\end{array}$ & $\begin{array}{l}-0,63 \pm \\
0,11^{\mathrm{a}}\end{array}$ & $\begin{array}{c}16,30 \pm \\
1,48^{\mathrm{a}}\end{array}$ \\
\hline
\end{tabular}

Keterangan: $\mathrm{A}$ = Bahan dari singkong parut; $\mathrm{B}=$ Bahan dari tepung singkong); $\mathrm{C}=$ Bahan dari campuran tapioka:tepung asia (3:1). Huruf yang berbeda pada kolom yang sama menunjukkan perbedaan yang nyata $(P<0,05)$ 
Hal ini berarti pada pembuatan singkong parut dan tepung singkong tidak semua pati keluar dari matriksnya sehingga rengginang tidak mengembang dengan maksimal. Ekstraksi pati singkong menjadi tapioka mampu mengeluarkan granula pati dari singkong sehingga pengembangan rengginang dapat lebih maksimal.

Pengembangan volume rengginang singkong juga dipengaruhi oleh kandungan amilopektin bahan pangan. Produk pangan dengan kandungan amilopektin yang lebih tinggi (amilosa rendah) memiliki kecenderungan lebih mengembang saat digoreng (Jiamjariyatam et al., 2015). Penggunaan perbandingan tapioka dan tepung asia dalam pembuatan rengginang juga menggunakan proporsi tapioka lebih banyak dibandingkan rendemen yang dihasilkan. Proporsi tapioka dan tepung asia yang diperoleh dari rendemen sebesar 23,08:8,55 (2,70:1), sedangkan pada pembuatan rengginang menggunakan proporsi 3:1. Tapioka memiliki kandungan pati sekitar $85 \%$ dengan komponen lain seperti serat, lemak, dan protein yang sangat rendah, sementara pada tepung asia hanya mengandung pati sekitar $40 \%$ dan serat mencapai 23\% (Musita 2018; Oladunmoye et al., 2014), sehingga semakin banyak jumlah tapioka yang ditambahkan daya pengembangan kerupuk yang dihasilkan semakin besar.

Tekstur merupakan salah satu atribut penting pada produk kerupuk dan sejenisnya. Analisis tekstur dilakukan dengan menggunakan Texture Analyzer. Atribut yang diuji pada analisis tekstur adalah kerenyahan (kerapuhan) dan kekerasan rengginang singkong matang. Hasil analisis pada Tabel $5 \mathrm{me}-$ nunjukkan bahwa kerenyahan rengginang formula $B$ dan formula $C$ tidak berbeda signifikan, tetapi berbeda signifikan dengan formula $A$. Sementara kekerasan ketiga formula tidak berbeda signifikan. Kekerasan dan kerenyahan berhubungan dengan kandungan amilosa pada produk. Kandungan amilosa yang tinggi secara signifikan dapat meningkatkan nilai kekerasan dan kerenyahan produk, serta menurunkan rasio pengembangan produk (Jiamjariyatam et al., 2015).

Hasil analisis warna rengginang singkong pada Tabel 5 menunjukkan bahwa rengginang singkong formula B lebih berwarna kecoklatan dengan nilai kecerahan $(L)$ paling rendah dan nilai b paling tinggi. Formula $\mathrm{C}$ merupakan sampel dengan warna paling putih yang ditandai dengan nilai $L$ paling tinggi dan nilai $b$ paling rendah. Warna pada rengginang singkong dapat dipengaruhi oleh bahan baku yang digunakan maupun terbentuk selama proses penggorengan. Pengeringan dalam proses pembuatan tepung singkong membutuhkan waktu yang cukup lama sehingga sangat memungkinkan terjadinya reaksi pencoklatan enzimatis. Reaksi pencoklatan ini menghasilkan tepung dengan nilai derajat putih lebih rendah. Proses penggorengan juga memengaruhi perubahan warna bahan pangan. Penurunan nilai kecerahan $(L)$ pada produk penggorengan mengindikasikan terjadinya reaksi pencoklatan dan pembentukan crust akibat dari paparan suhu tinggi terutama pada penggorengan suhu atmosferik (Oyedeji et al., 2017).

\section{Pengaruh bahan baku terhadap karakteristik sensori rengginang singkong}

Hasil analisis sensori penerimaan panelis terhadap kenampakan rengginang singkong disajikan pada Tabel 6. Rengginang singkong mentah dari ketiga perlakuan memiliki tingkat penerimaan yang cukup baik (mendekati agak suka hingga suka). Perlakuan singkong parut memiliki penerimaan paling rendah dengan skor 4,90 (antara netral dan agak suka), sedangkan perlakuan tepung singkong memiliki penerimaan paling tinggi dengan skor 5,93 (antara agak suka sampai suka).

Analisis sensori terhadap rengginang singkong matang dilakukan untuk mengetahui tingkat penerimaan panelis terhadap atribut warna, aroma, rasa, tekstur, dan keseluruhan masing-masing perlakuan. Berdasarkan hasil analisis sensori rengginang singkong pada Tabel 6 , ketiga formula memiliki penerimaan yang sama sensori untuk semua atribut sensori pada taraf $95 \%$. Hasil analisis terhadap penerimaan secara keseluruhan menunjukkan bahwa ketiga formula dapat diterima oleh panelis dengan rentang agak suka sampai suka, meskipun terdapat perbedaan persepsi penerimaan pada kenampakan rengginang mentah.

\section{Hasil proksimat produk terpilih}

Analisis proksimat dilakukan untuk mengetahui komposisi kimia produk rengginang singkong terpilih. Pemilihan produk yang dianalisis proksimat didasarkan pada karakteristik fisik dan sensori rengginang matang yang telah dilakukan.

Tabel 6. Hasil analisis sensori rengginang singkong matang

\begin{tabular}{ccccccc}
\hline \multirow{2}{*}{ Formula } & Mentah & \multicolumn{5}{c}{ Matang } \\
\cline { 2 - 7 } & Kenampakan & Warna & Aroma & Tekstur & Rasa & Keseluruhan \\
\hline A & $4,90^{\mathrm{a}}$ & $5,43^{\mathrm{a}}$ & $5,17^{\mathrm{a}}$ & $5,70^{\mathrm{a}}$ & $5,67^{\mathrm{a}}$ & $5,60^{\mathrm{a}}$ \\
B & $5,93^{\mathrm{a}}$ & $5,17^{\mathrm{a}}$ & $5,13^{\mathrm{a}}$ & $6,03^{\mathrm{a}}$ & $5,73^{\mathrm{a}}$ & $5,80^{\mathrm{a}}$ \\
C & $5,40^{\mathrm{b}}$ & $5,37^{\mathrm{a}}$ & $4,73^{\mathrm{a}}$ & $5,80^{\mathrm{a}}$ & $5,63^{\mathrm{a}}$ & $5,57^{\mathrm{a}}$ \\
\hline
\end{tabular}

Keterangan: $\mathrm{A}=$ Bahan dari singkong parut; $\mathrm{B}=$ Bahan dari tepung singkong; $\mathrm{C}=$ Bahan dari campuran tapioka: tepung asia (3:1). Huruf yang berbeda pada kolom yang sama menunjukkan perbedaan yang nyata $(P<0,05)$ 
Hasil analisis sensori menunjukkan tidak adanya perbedaan penerimaan panelis terhadap semua atribut sensori rengginang singkong matang secara nyata, sehingga dapat dikatakan bahwa ketiga formula rengginang singkong tersebut memiliki penerimaan yang sama. Salah satu dari tiga formula tersebut diambil sebagai model untuk analisis proksimat rengginang singkong matang. Analisis ini bertujuan untuk mengetahui secara umum kandungan air, abu, lemak, protein, dan karbohidrat total. Rengginang singkong dari formula $\mathrm{C}$ memiliki penerimaan sensori sama dengan formula $A$ dan $B$, tetapi memiliki rasio pengembangan dan kerenyahan paling tinggi, serta berwarna lebih cerah sehingga dipilih untuk dilakukan uji proksimatnya.

Hasil analisis pada Tabel 7 menunjukkan bahwa produk rengginang singkong terpilih memiliki kadar air, abu, dan protein rendah. Singkong memiliki kandungan protein dan abu yang rendah (Alamu et al., 2017). Singkong memiliki kualitas protein yang sangat rendah dengan komposisi asam amino esensial yang terbatas (Morgan dan Choct, 2016). Kadar air yang rendah ini diperoleh akibat adanya proses penggorengan yang menyebabkan air pada rengginang menguap. Kadar karbohidrat yang tinggi pada rengginang terpilih berasal dari bahan dasar yang digunakan. Singkong mengandung total padatan yang didominasi oleh karbohidrat terutama kandungan patinya.

Tabel 7. Hasil analisis proksimat produk terpilih (Formula $\mathrm{C}$ ) dalam basis basah

\begin{tabular}{lc}
\hline \multicolumn{1}{c}{ Komponen } & Kadar $(\%$ b/b) \\
\hline Air & $2,83 \pm 0,02$ \\
Abu & $1,87 \pm 0,02$ \\
Lemak & $30,47 \pm 0,06$ \\
Protein & $0,42 \pm 0,00$ \\
Karbohidrat by difference & $64,42 \pm 0,02$ \\
\hline
\end{tabular}

\section{KESIMPULAN}

Rengginang singkong dapat dibuat dari sediaan bahan baku yang berbeda. Jenis bahan baku memberikan pengaruh yang nyata terhadap karakteristik fisik rengginang singkong. Rengginang dari singkong parut menghasilkan produk dengan rasio pengembangan dan kerenyahan paling rendah. Rengginang dari tepung singkong memiliki rasio pengembangan dan kerenyahan lebih tinggi, tetapi memiliki tingkat kecerahan (L) paling rendah dan cenderung berwarna coklat. Rengginang dari campuran tapioka dan tepung asia (3:1) memiliki kerenyahan, rasio pengembangan, tingkat kecerahan, dan warna putih tertinggi dibandingkan dengan formula yang lain pada taraf $95 \%$. Hasil analisis sensori menunjukkan bahwa ketiga formula tersebut tidak berbeda nyata pada taraf $95 \%$ untuk semua atribut sensori yang diujikan. Rengginang dari campuran tapioka dan te- pung asia (3:1) dipilih sebagai formula terbaik karena memiliki rasio pengembangan, kerenyahan, dan kecerahan yang paling tinggi dibandingkan dengan formula lainnya pada taraf $95 \%$.

\section{DAFTAR PUSTAKA}

[AOAC] Association of Official Analytical Chemistry. 2005. Official methods of analysis of AOAC International $18^{\text {th }}$ edition. AOAC International, Virginia (US).

Ahmad L. 2009. Modifikasi Fisik Pati Jagung dan Aplikasinya untuk Perbaikan Kualitas Mi Jagung. [Tesis]. Bogor: Fakutlas Teknologi Pertanian, Institut Pertanian Bogor.

Alamu EO, Maziya-Dixon B, Dixon AG. 2017. Evaluation of proximate composition and pasting properties of high quality cassava flour (HQCF) from cassava genotypes (Manihot esculenta Crantz) of $\beta$-carotene-enriched roots. LWTFood Sci Technol 86: 501-506. DOI: 10.1016/j. Iwt.2017.08.040.

Baljeet SY, Ritika BY, Roshan LY. 2010. Studies on functional properties and incorporation of buckwheat flour for biscuit making. Int Food Res J 17: 1067-1076.

[BPS] Badan Pusat Statistika. 2017. Produksi ubi kayu menurut provinsi (ton), 1993-2015. https:// www.bps.go.id/linkTableDinamis/view/id/880. [16 Desember 2017]

[BSN] Badan Standardisasi Nasional. 1996. Tepung Singkong SNI 01-2997-1996. Jakarta (ID): BSN.

[BSN] Badan Standardisasi Nasional. 2011. Tapioka SNI 3451-2011. Jakarta (ID): BSN.

Charoenkul N, Uttapap D, Pathipanawat W, Takeda Y. 2011. Physicochemical characteristics of starches and flours from cassava varieties having different cooked root textures. LWT- Food Sci Technol 44: 1774-1781. DOI: 10.1016/j.Iwt. 2011.03.009.

Elida S, Hamidi W. 2009. Analisis pendapatan agroindustri rengginang ubi kayu di kabupaten Kampar provinsi Riau. J Ekonomi 17: 109-119.

Feliana F, Laenggeng AH, Dhafir F. 2014. Kandungan gizi dua jenis varietas singkong (Manihot esculenta) berdasarkan umur panen di Desa Siney Kecamatan Tinombo Selatan Kabupaten Parigi Moutong. Jurnal e-Jipbiol 2: 1-14.

Ginting FS. 2014. Pengaruh Perendaman Umbi Singkong dalam Larutan Asam Asetat terhadap Karakteristik Mutu Keripik Singkong. [Skripsi]. Bogor: Fakultas Teknologi Pertanian, Institut Pertanian Bogor.

Hendrasmoro. 2012. Social entrepreneurship makanan ringan berbahan baku hasil bumi lokal. $\mathrm{J}$ Entrepreneur dan Entrepreneurship 1: 41-47. 
Huda N, Leng AL, Yee CX, Herpandi. 2010. Chemical composition, colour and linear expansion properties of Malaysian commercial fish cracker (keropok). As J Food As-Ind 3: 473-482.

Huda N, Putra AA, Ahmad R. 2011. Physicochemical and nutritional characteristics of Indonesian Buffalo skin crackers. Int J Meat Sci 1: 36-51. DOI: 10.3923/ijmeat.2011.36.51.

Jiamjariyatam R, Kongpensook V, Pradipasena P. 2015. Effects of amylase content, cooling rate and aging time on properties and characteristics of rice starch gels and puffed products. $J$ Cereal Sci 61: 16-25. DOI: 10.1016/j.jcs.2014. 10.001.

Kusumawardhani AR. 2013. Pembuatan Tepung Tapioka dengan Pengering Semprot dan Pengering Cabinet serta Aplikasinya pada Produk Pilus di PT Garudafood Putra-Putri Jaya. [Skripsi]. Bogor: Fakultas Teknologi Pertanian, Institut Pertanian Bogor.

Morgan NK, Choct M. 2016. Cassava: Nutrient composition and nutritive value in poultyry diets. Anim Nutr 2: 253-261. DOI: 10.1016/j.aninu.20 16.08.010.

Muhandri T. 2012. Mekanisme proses pembuatan mi berbahan baku jagung. Buletin Teknol Pascapanen Pertanian 8: 71- 79.

Musita N. 2018. Kajian sifat fisikokimia tepung onggok industri besar dan industri kecil. Majalah Teknologi Agro Industri (Tegi) 10: 19-24.

Mustapha NA, Rahmat FFB, Ibadullah WZW, Hussin ASM. 2015. Development of jackfruit crackers: Effects of starch type and jackfruit level. Int $\mathrm{J}$ Adv Sci Eng Inf Tech 5: 330-333. DOI: 10.1851 7/ijaseit.5.5.583.

Nashirudin H. 2009. Pengembangan Produk Opak Berbahan Baku Buru Hotong (Setaria italica L. Beauv.). [Skripsi]. Bogor: Fakultas Teknologi Pertanian, Institut Pertanian Bogor.

Naveen K, Khatkar BS, Kaushik R. 2013. Effect of reducing agents on wheat gluten and quality characteristics of flour and cookies. AUDJGFood Technol 37: 68-81.

Norton AD, Greenwood RW, Noble I, Cox PW. 2011. Hot air expansion of potato starch pellets with different water contents and salt concentrations. J Food Eng 105: 119-127. DOI: 10.1016/j.jfood eng.2011.02.014.

Nurul H, Boni I, Noryati I. 2009. The effect of different ratios of Dory fish to tapioca flour on the linear expansion, oil absorpsion, colour and hardness of fish crackers. Int Food Res J 16: 159-165.

Oladunmoye OO, Aworh OC, Maziya-Dixon B, Erukainure OL, Elemo GN. 2014. Chemical and functional properties of cassava starch, durum wheat semolina flour, and their blends. Food Sci Nutr 2:132-138. DOI: 10.1002/fsn3.83.

Oyedeji AB, Sobukola OP, Henshaw F, Adegunwa MO, ljabadeniyi OA, Sanni LO, Tomlins KI. 2017. Effect of frying treatments on texture and colour parameters of deep fat fried yellow fleshed cassava chips. J Food Qual 2017: 1-10. DOI: 10.1155/2017/8373801.

Rasulu H, Yuwono SS, Kusnadi J. 2012. Karakteristik tepung ubi kayu terfermentasi sebagai bahan pembuatan sagukasbi. J Teknol Pertanian 13: 1-7.

Saeleaw M, Schleining G. 2011. Effect of frying parameters on crispness and sound emission of cassava crackers. J Food Eng 103: 229-236. DOI: 10.1016/j.jfoodeng.2010.10.010.

Setyaningsih D, Apriyantono A, Sari MP. 2010. Analisis Sensori untuk Industri Pangan dan Agro. IPB Press, Bogor.

Syamsir E, Hariyadi P, Fardiaz D, Andarwulan N, Kusnandar F. 2011. Karakterisasi tapioka dari lima varietas ubikayu (Manihot utilissima Crantz) asal Lampung. J Agrotek 5: 93-105.

Zhu F. 2015. Composition, structure, physicochemical properties, and modifications of cassava starch. Carbohyd Polym 122: 456-480. DOI: 10. 1016/j.carbpol.2014.10.063. 